\title{
Issues of Quality of Expert Opinion, and Certain Aspects of Forensic Expert Safety in Criminal, Civil and Administrative Proceedings
}

\begin{abstract}
Kofanov Andrii
Legal Advisor to the Council of Europe Programme "Decentralization and Territorial Consolidation in Ukraine”, PhD of Juridical Sciences, Associate

Professor, Professor of Department of Forensic Support and Forensic Expertise of the National Academy of Internal Affairs, Kiev, Ukraine ORCID ID 0000-0002-5242-2518 kofanov_andrey@ukr.net
\end{abstract}

\section{Svoboda Eugenia}

PhD of Juridical Sciences, Associate Professor, Professor of Department of Forensic Support and Forensic Expertise of the National Academy of Internal Affairs, Kiev, Ukraine ORCID ID 0000-0002-8639-8333 jeechka@ukr.net

\section{Mikhalchuk Tetiana}

PhD of Juridical Sciences, Senior Teacher of Forensic Support and Forensic Expertise of the National Academy of Internal Affairs, Kyiv, Ukraine ORCID ID 0000-0002-3063-902X mixalchuk@ukr.net

\section{Morhun Nadiia}

PhD of Juridical Sciences, Deputy Director of Educational and Research Institute №1 for educational, scientific and research works, National Academy of Internal Affairs, Kyiv, Ukraine ORCID ID 0000-0002-2997-9975 protektra@i.ua

\section{Symchuk Anatolii}

Senior Teacher of Forensic Support and Forensic Expertise of the National Academy of Internal Affairs, Kiev, Ukraine ORCID ID 0000-0002-8663-8210 symchukas@gmail.com

\footnotetext{
Abstract

The concept of quality may be regarded as a composite structure comprising the support for the following elements: legal, scientific and technological, methodological, organisational, logistical. The quality of expert investigation is not an abstract concept; it actually exists and has a certain content that expresses substantial
} 
certainty, since it results in an expert opinion - judicial evidence. An expert opinion has a procedural (legal), scientific and technological aspects. The 'quality of forensic examination' concept therefore has a procedural (legal), scientific and technological content.

Key words: legal protection of the forensic expert, physical protection of the forensic expert, quality of expert opinion, court proceedings, forensic expert regulation

Introduction. Thus, the very concept of 'quality of forensic examination' is composite and requires a comprehensive, systematic approach to its study [1, pp. 33-36; 10].

The concept of 'quality' is closely related to that of 'efficiency'. It is generally remarked that an expert investigation should be complete, comprehensive, objective, etc., whereas an expert opinion should be complete, clear, consistent, coherent, informed, etc. Therefore, examining the efficiency of expert investigation and measures to improve it involves a simultaneous analysis of factors that raise the investigation quality and level, as well as reliability and validity of expert's findings.

In the legal literature, less attention is given to the concept of 'quality'. For example, I. P. Kononenko defines the quality of a forensic expert opinion as 'a totality of legal, scientific and technological properties, which comply with the law and other regulations governing the conduct of forensic examination, and of instructional research rules applicable to a forensic expert opinion as judicial evidence' $[2$, pp. 31-40; 11]. This definition is not objectionable on the whole. It makes it evident that quality describes outputs of a (forensic examination) system operation at its individual stages, i.e. a 'finished product', whereas efficiency describes the entire system, showing how this system functions in accordance with the tasks and objectives it was intended to address upon its creation. Some of these tasks are focused on delivering a product of a certain quality (such as giving an informed opinion); others refer to a procedure for the operation or to the process itself (such as timeliness of forensic examination). However, both are intended to deliver a certain result that reflects the degree of system efficiency.

It seems reasonable to conclude that efficiency is a broader category than quality and encompasses the latter.

Quality indicators of expert investigation are closely related to efficiency indicators of expert investigation.

Quantity indicators of efficiency 'quality' in an expert's activities include:

1. Indicator of achieved objective of establishing evidence. It represents the ratio 
between the number of questions posed and resolved. Those questions are regarded as resolved to which answers have been given in a categorical (positive or negative) form, since such answers always contain actual data of evidentiary value. Resolved questions should also include those the answers to which have been given in conditionally categorical, alternative or probabilistic forms, since conclusions containing such findings may be used to develop investigative leads. Only those questions should be regarded as unresolved the answers to which contain the wording 'resolving this question was not possible.'

2. Number of forensic errors made by an expert. This indicator is derived by comparing findings of initial and repeat examinations, forensic examinations and case files of concluded proceedings (in which a final verdict or judgement has been passed), as well as by reviewing the supervised proceedings, and by monitoring outgoing expert opinions arranged at an expert institution. Here, high quality implies minimising expert's errors or their complete elimination.

3. Observance of deadlines. An indicator of this criterion is the number of questions that have been resolved in the time spent on the examination over the deadline established by departmental instructions. Here, the extent and quality of examination may be determined by the ratio between the number of questions resolved before the deadline and all questions put to an expert.

4. Indicator of law observance in the conduct of examinations. It includes the number of questions resolved without violating examination procedural rules.

5. Completeness and clarity of opinion. This goal is achieved when no unanswered questions or unexplored items have been left after examination; no unsupported statements or unclear answers, offering different interpretations and thus preventing their use by an investigator or court, are included in the opinion. An indicator here may be the ratio between fully and clearly stated findings and all findings made.

Quality criteria and indicators of an expert investigation when addressing the tasks put before an expert from the viewpoint of end results of a forensic examination, and their relation to the criteria of a forensic examination as a whole were examined above [3, p. 25$30 ; 12]$.

However, it is hard to assess the quality of an expert's work by using quantity indicators only. One should proceed from a distinction made between two large groups of 
quality indicators in an expert investigation: indicators directly related to the investigation and those associated with drawing up an opinion that reflects the investigation progress and the expert's findings.

Indicators from the first group may include:

A match between the selected methodology, on the one hand, and the specifics of investigated objects and the task put before the expert, on the other;

Advanced level of investigation (applying a set of modern investigation techniques);

Rationality of investigation (choosing the shortest path to solve a problem);

Economical use of test substances; accuracy of assessing the totality of identified elements (its compliance with the developed criteria);

Proactive approach by the expert, as may be necessary to establish facts relevant to the case.

Indicators from the second group may include scientific validity, completeness, clarity and visualisation of the opinion. This aspect is associated with efficiency assessment of an expert's operations and is relevant within an institutional structure, although outputs from such operations have a direct impact on attainment of general goals in forensic examination.

Scientific validity and completeness of an opinion are manifested in the following:

Accuracy and consistency in the description of items, investigation process, appearance of investigated items, thereby enabling their individualisation;

Elements identified during the investigation through application of scientific techniques; objective links established between the identified elements and the sought fact;

A statement of interim findings arrived at during the investigation and used to formulate the final findings;

A statement of final findings based on the assessment of the totality of identified elements;

No unanswered questions.

Clarity is characterised by logical reasoning, accessibility of presentation for laymen (explanation of special terms, etc.), a match between the findings and the questions posed. Visualisation is determined by the necessary visual materials attached to the opinion.

Thus, quality and efficiency in investigation are fairly interlinked — higher quality of 
the investigation is guaranteed to increase its efficiency.

Because of its geographical and geopolitical position, Ukraine cannot insulate or protect itself against the phenomena that are currently inherent in any other country in the world. In this regard, V. V. Stashys was right to draw attention to the fact that an upsurge in organised crime both in Ukraine and in most other countries had been observed recently. This social phenomenon poses danger not only to individual countries, but also to the entire global community. [4, p. 133; 10]

Investigations in criminal cases related to the activities of transnational criminal organisations are associated with a certain degree of risk facing the individuals engaged in identification, prevention, suppression, detection or investigation of crimes, as well as in court hearings of criminal cases. Without optimum conditions created for proper administration of justice, including by ensuring the safety of individuals participating in criminal proceedings, no fight against organised crime through the use of criminal law methods would be possible. Under Article 65 of the Criminal Procedure Code of Ukraine (previous version), sources of evidentiary information on the basis of which an investigating authority, investigator or court establish the presence or absence of a socially dangerous act, culpability of its perpetrator or other circumstances relevant to the proper adjudgement include a forensic expert opinion. Article 77.3 of the CPCU provided for the expert's right to protection, where eligible $[5, \text { p. } 15 ; 11]^{1}$.

Article 7 of the Law of Ukraine 'On Forensic Examination' stipulates that forensic activities in Ukraine shall be carried out by specialised state institutions that include research and other forensic institutions of the Ministry of Justice and the Ministry of Health, as well as forensic services of the Ministry of Internal Affairs and the Ministry of Defence, Security Service and the State Border Guard Service of Ukraine. Furthermore, forensic activities may be carried out by individuals on commercial basis under one-time contracts [6, p. 232; 12].

Safety of forensic experts is regulated by the Law of Ukraine 'On Ensuring the Safety of Persons Participating in Criminal Process' [7, p. 51; 10]. Ensuring the safety of individuals participating in criminal proceedings, under Article 1 of the Law of Ukraine 'On Ensuring the Safety of Persons Participating in Criminal Process', involves legal, administrative,

\footnotetext{
${ }^{1}$ These CPCU provisions were in force in their previous revision until 01/12/2013. We believe that they still retain their relevance.
} 
technical and other measures taken by law enforcement authorities to protect life, homes, health and property of these persons against unlawful encroachments, with the aim of establishing the necessary conditions for proper administration of justice. In Article 2.(f) of this Law, a forensic expert is directly listed among the individuals entitled to protection, where eligible.

Entitlement of forensic experts to safety is regulated not only by this Law. Employees of specialised state institutions that perform forensic examinations (Ministry of Justice, Ministry of Health, Ministry of Internal Affairs, Ministry of Defence, Security Service, State Border Guard Service of Ukraine) are law enforcement officers.

Performing forensic examinations constitutes the exercise of (law) enforcement functions, which, under Article 2.1 of the Law of Ukraine 'On State Protection of Judicial and Law Enforcement Employees', is an attribute of law enforcement authorities [8, p. 50; 11]. By its Article 1, this Law establishes a system of special measures for the state protection of judicial and law enforcement employees from obstructing the exercise of their statutory duties and rights. It is also intended to protect these individuals, in connection with their official activities, and their immediate family against encroachments on their life, health, home or property. It would thus seem appropriate to stipulate that those forensic experts who are employees of state research or other expert institutions of the Ministry of Justice and Ministry of Health, as well as of expert services of the Ministry of Internal Affairs, Ministry of Defence and the Security Service, shall be protected entities under the Law of Ukraine 'On State Protection of Judicial and Law Enforcement Employees'.

Forensic experts from among the persons performing forensic activities on a commercial basis, as well as individuals who provide forensic examinations under one-time contracts, are entitled to protection in the manner prescribed by the Law of Ukraine 'On Ensuring the Safety of Persons Participating in Criminal Process'.

The scope of protective measures stipulated by these two Laws for various categories of persons is also different. However, forensic activities carried out by employees of state expert research institutions are usually associated with the support for criminal proceedings. By contrast, private business employees are generally engaged as forensic experts in civil or economic legal proceedings under one-time contracts [9, p. 202-204; 10;11; 12]. 
A more specific legislative definition of forensic experts' protection, depending on the departmental affiliation of forensic or other institutions, would put individuals performing forensic examinations as part of their official duties on an equal footing with other employees from these institutions.

Conclusion. It should be noted in summary that, in our opinion, setting up a system of reliable legal protection for a forensic expert as a participant in legal proceedings and a source of expert opinion would preclude (to a large extent) any potential physical or psychological pressure and would have a correspondent impact on the quality of investigation and validity of its findings.

\section{References}

1. Redin A. M. On Quality of Forensic Examination Findings and Their Evidentiary Value, in Forensic Science and Examination (Kyiv, 1979), vol. 19, pp. 33-36.

2. Kononenko I. P. Certain Procedural Specifics of Forensic Examinations Performed at Expert Institutions, in Forensic Science and Examination (Kyiv, 1976), vol. 12, pp. 31-40.

3. Matiychenko B. A. Selecting Criteria and Indicators for Efficiency Analysis of Forensic Activities in the Expert Institutions' Scientific Research and Practice, in Institutional and Legal Issues of Forensic Examination: Collected Papers (Moscow, 1982), pp. 25-30.

4. Stashys $V . V$. Certain Aspects of Combatting Organised Crime, in Bulletin of the Academy of Legal Sciences of Ukraine (2000), No. 4, p. 133.

5. Criminal Procedure Code of Ukraine, in Official Bulletin of the Verkhovna Rada of Ukrainian SSR (1961), No. 2, p. 15.

6. On Forensic Examination, the Law of Ukraine No. 4038-XII dated 25 February 1994, in Official Bulletin of the Verkhovna Rada of Ukraine (1994), No. 28, p. 232.

7. On Ensuring the Safety of Persons Participating in Criminal Process, the Law of Ukraine No. 3782-XII dated 23 December 1993, in Official Bulletin of the Verkhovna Rada of Ukraine (1994), No. 11, p. 51.

8. On State Protection of Judicial and Law Enforcement Employees, the Law of Ukraine No. 3781-XII dated 23 December 1993, in Official Bulletin of the Verkhovna Rada of Ukraine (1994), No. 11, p. 50.

9. Repeshko P. I. On the Matter of Protecting Forensic Experts in Ukraine's Criminal Process: Topical Policy Issues, in Collected Papers of the Odessa State Law Academy (Odesa, 2004), No. 21, pp. 202-204.

10. Forensic experts' mistakes: theoretical and practical aspects. URL: 
https://doi.org/10.32370/online/2019_03_25_2

11. "Lost opportunities" of preliminary researches in the conditions of the current Criminal Procedure Code of Ukraine. URL:

http://elar.naiau.kiev.ua/jspui/handle/123456789/9567

12. Analytical reference to the project of the Law of Ukraine "About amendments to the Criminal Procedure Code of Ukraine on the Procedure for Appointment of Expertise". URL: http://bsm.com.ua/2011-08-07-02-51-49/item/200-biznes-i-bezopasnost-3-2018 